6. Hanada $Y$, Kawahara $Y$, Ohnishi YN, Shuto T, Kuroiwa M, Sotogaku N, et al. p11 in cholinergic interneurons of the nucleus accumbens is essential for dopamine responses to rewarding stimuli. eNeuro. 2018;5, https://doi.org/10.1523/ ENEURO.0332-18.2018.

7. Admon R, Holsen LM, Aizley $H$, Remington A, Whitfield-Gabrieli S, Goldstein $J M$, et al. Striatal hypersensitivity during stress in remitted individuals with recurrent depression. Biol Psychiatry. 2015;78:67-76. https://doi.org/10.1016/j. biopsych.2014.09.019.

8. Pizzagalli DA, Holmes AJ, Dillon DG, Goetz EL, Birk JL, Bogdan R, et al. Reduced caudate and nucleus accumbens response to rewards in unmedicated individuals with major depressive disorder. Am J Psychiatry. 2009;166:702-10. https://doi.org/ 10.1176/appi.ajp.2008.08081201.
Open Access This article is licensed under a Creative Commons Attribution 4.0 International License, which permits use, sharing, adaptation, distribution and reproduction in any medium or format, as long as you give appropriate credit to the original author(s) and the source, provide a link to the Creative Commons license, and indicate if changes were made. The images or other third party material in this article are included in the article's Creative Commons license, unless indicated otherwise in a credit line to the material. If material is not included in the article's Creative Commons license and your intended use is not permitted by statutory regulation or exceeds the permitted use, you will need to obtain permission directly from the copyright holder. To view a copy of this license, visit http://creativecommons.org/licenses/by/4.0/.

\title{
Dopamine release drives motivation, independently from dopamine cell firing
}

\author{
Ali Mohebi (iD) and Joshua D. Berke ${ }^{1}$ \\ Neuropsychopharmacology (2020) 45:220; https://doi.org/10.1038/s41386-019-0492-7
}

Despite decades of study, fundamental aspects of dopamine biology are still being revealed.

Dopamine release in the forebrain has at least two distinct functions: it invigorates current behavior (motivation) [1] and influences future behavior (learning) [2]. The learning role seems, at least in part, to involve brief bursts of dopamine cell firing signaling reward prediction errors [3]. This "phasic" dopamine signal helps adjust future reward expectations, through the modification of synaptic strengths in forebrain targets [4]. This is a compelling account of reinforcement learning mechanisms, but does not describe how dopamine achieves more immediate motivational functions.

It has been argued that motivation is mediated by distinct, slower changes in "tonic" dopamine cell firing. This now appears not to be the case [5]. In rats working for sugar rewards, we directly compared the firing of optogenetically identified midbrain dopamine cells (in the ventral tegmental area) with forebrain dopamine release (measured using microdialysis, voltammetry, and optical sensors). We found that dopamine release increases with reward expectation-and thereby enhances the animals' willingness to expend effort $[1,5]$. Crucially, however, we found no corresponding change in dopamine cell firing.

Instead, this motivational aspect of dopamine release seems to be locally controlled within forebrain subregions. In both striatum and cortex we found specific "hotspots" (nucleus accumbens core and ventral prelimbic cortex) where dopamine release covaried with reward expectation [5]. These spatial foci stand in contrast to the canonical concept of dopaminergic reward prediction errors being "broadcast" throughout the forebrain.

There are many mechanisms that can achieve local control of dopamine release [6], most obviously the nicotinic acetylcholine receptors on dopamine terminals. The axons of striatal cholinergic interneurons form a very dense network of release sites closely intermingled with dopamine varicosities. Artificial stimulation of striatal cholinergic neurons very rapidly evokes dopamine release.

Although the local control of dopamine release has long been studied, its functional and computational significance is only now coming into focus. A better understanding of how dopamine release is regulated in behaving animals may provide a critical foundation for our understanding of neurological and psychiatric disorders, and the development of novel pharmacological therapies.

\section{FUNDING AND DISCLOSURE}

Our work on dopamine has been supported by the National Institute on Drug Abuse, the National Institute of Mental Health, the National Institute on Neurological Disorders and Stroke, the University of Michigan, Ann Arbor, and the University of California, San Francisco. The authors declare no competing interests.

\section{ADDITIONAL INFORMATION}

Publisher's note: Springer Nature remains neutral with regard to jurisdictional claims in published maps and institutional affiliations.

\section{REFERENCES}

1. Hamid AA. et al. Mesolimbic dopamine signals the value of work. Nat. Neurosci. 2015:1-13. https://doi.org/10.1038/nn.4173

2. Berke JD. What does dopamine mean? Nat. Neurosci. 2018;1. https://doi.org/ 10.1038/s41593-018-0152-y

3. Schultz W, Dayan P, Montague PR. A neural substrate of prediction and reward. Science. 1997:275:1593-1599.

4. Yagishita S. et al. A critical time window for dopamine actions on the structural plasticity of dendritic spines. Science. 2014;345:1616-1620.

5. Mohebi A. et al. Dissociable dopamine dynamics for learning and motivation. Nature. 2019. https://doi.org/10.1038/s41586-019-1235-y

6. Rice ME, Patel JC, Cragg SJ. Dopamine release in the basal ganglia. Neuroscience. 2011;198:112-137. 